\title{
Sacrifices in Chronicles: How Priestly Are They?
}

\section{Introduction}

As the title suggests the purpose of this chapter is to explore the depiction of the sacrificial cult in Chronicles in the light of the presentation of sacrifices in Leviticus. Scholars such as David Janzen and Sara Japhet agree on the centrality of the cult in Chronicles. ${ }^{1}$ Thus Japhet would say concerning the temple that what strikes the reader "as almost every study has noted, is the book's emphasis on the subject." ${ }^{2}$ To state that the cult is central in Leviticus is saying the very obvious. This essay aims to scrutinise the Chronicler's presentation of the sacrificial cult from the Priestly perspective of Leviticus. It will become clear that at times there is a fair amount of overlap or similarity between the cult presented by the Chronicler and the one described in Leviticus. At other times there are evident tensions between the two portrayals of the cult.

Why would one approach the presentation of the cult from the perspective of Leviticus? One answer could refer to historical context. Most scholars who engage with dating the final compilations of these books would date the Chronicler to a slightly later period than Leviticus. ${ }^{3}$ Both are probably from the Persian Period,

1 David Janzen, The Social Meanings of Sacrifice in the Hebrew Bible: A Study of Four Writings, BZAW 344 (Berlin: De Gruyter, 2004), 209; Sarah Japhet, The Ideology of the Book of Chronicles and its Place in Biblical Thought, trans. A. Barber, BEATAJ 9 (Berlin: Peter Lang; 1997; repr. Winona Lake, IN: Eisenbrauns, 2009). See also Ehud Ben Zvi, "Purity Matters in the Book of Chronicles: A Kind of Prolegomenon," in Purity, Holiness, and Identity in Judaism and Christianity: Essays in Memory of Susan Haber, eds. Carl S. Ehrlich, Anders Runesson and Eileen Schuller (Tübingen: Mohr Siebeck, 2013), 37-54, here 39.

2 Japhet, The Ideology of the Book, 175.

3 Scholars such as Klaus Grünwaldt, Das Heiligkeitsgesetz Leviticus 17-26: Ursprüngliche Gestalt, Tradition und Theologie, BZAW 271 (Berlin: De Gruyter, 1999), 379-81, whose work focused on the Holiness Code, dates this text to the middle of the fifth century BCE. At this time, most of Leviticus 1-16 was already in place. Christophe Nihan, From Priestly Torah to Pentateuch, FAT II 25 (Tübingen: Mohr Siebeck, 2007), 574, argues for the late fifth century for the completion of what he calls $\mathrm{H}$. But then, the two dark horses of any attempt at diachronic reconstructions of the development of the text of Leviticus are chapters 10 and 27, which probably came later. Thomas Hieke, Levitikus 1-15, HTKAT (Freiburg: Herder, 2014), 70, like Grünwaldt, thinks it was the middle of the fifth cen-

Esias E. Meyer, University of Pretoria 
but the Chronicler is later and takes us to the end of the Persian Period (if not the Hellenistic Period, as some would argue). ${ }^{4}$ Both presentations of the cult thus derive from a similar historical context.

A further answer has to do with the fact that some Chronicles scholars have already argued that the Chronicler was drawing from both "the Deuteronomistic tradition (which formed the main source for his historical work) and the priestly tradition, probably in mimetic fashion." ${ }^{5}$ The question is thus how did the Chronicler draw on the Priestly view of the cult in Leviticus.

One should keep in mind though that in terms of genre both texts are quite different. Apart from the fact that Leviticus is a mixture of apodictic and casuistic law with a narrative section here and there, Chronicles is another kind of text, mostly characterised by narratives and genealogies. ${ }^{6}$ Both books also depict two different narrative settings. Leviticus tells the story of Sinai, which is primarily understood as fictional, but it retells this story in the Persian context. In this narrative world there are no kings, since they appear only later in the story, but incidentally, it is told in a historical context where there are no longer any kings (except for Persian ones). The Chronicler tells his story in a similar historical context, but in his part of the story there are kings, and they need to be portrayed as characters. They need to have some kind of relationship with the cult in that

tury. I will not engage here with the dates put forward by members of the Kaufmann school. For the most recent challenge to that position see Konrad Schmid, "How to Identify a Persian Period Text in the Pentateuch," in On Dating Biblical Texts to the Persian Period, FAT II 101, eds. Richard J. Bautch and M. Lackowski (Tübingen, Mohr Siebeck, 2019), 101-18. Also see the diverse opinions in the contributions by Shimon Gesundheit, Erhard Blum, Jan Joosten, William M. Schniedewind, Thomas Römer, Noam Mizrahi, Jakob Wöhrle and Frank H. Polak in The Formation of the Pentateuch: Bridging the Academic Cultures of Europe, Israel, and North America, FAT 111, eds. Jan C. Gertz, Bernard M. Levinson, Dalit Rom-Shiloni and Konrad Schmid (Tübingen: Mohr Siebeck, 2016). My own understanding of dating Leviticus would be similar to the views of Blum, Römer, Wöhrle etc. which I suppose puts me very much in the European corner of this debate.

4 See the overviews provided by Louis C. Jonker, 1 \& 2 Chronicles, UBCS (Grand Rapids, MI: Baker Books, 2013), 8, or, Gary N. Knoppers, “Chronicles, First and Second Books of,” NIDB 1:621-31, here 624. Both argue for the fourth century BCE. Also, Steven L. McKenzie, 1-2 Chronicles, AOTC (Nashville: Abingdon, 2004), 29-31, regards "the second half of the fourth century (350-300 B.C.E.) being perhaps the most likely.”

5 Louis C. Jonker, Defining All-Israel in Chronicles: Multi-levelled Identity Negotiation in Late Persian-Period Yehud, FAT 106 (Tübingen: Mohr Siebeck, 2016), 236. Jonker gets the idea of "mimetic fashion” from Gary N. Knoppers, "The Relationship of the Deuteronomistic History to Chronicles: Was the Chronicler a Deuteronomist?,” in Congress Volume Helsinki 2010, ed. Martti Nissinen (Leiden: Brill, 2012), 307-41.

6 See Jonker, 1 \& 2 Chronicles, 5-6. Other genres mentioned are a letter and edict, prayers and speeches. 
story. As we will see below, the depiction of the cult becomes most interesting when certain kings enter the story.

The chapter will first present a brief overview of how the five sacrifices of Leviticus 1-7 are portrayed in the books of Chronicles. These are not the only sacrifices in the Old Testament and they are not the only sacrifices mentioned in Chronicles. It would be possible to present the Chronicler's view of sacrifice by focusing on the sacrificial terms which feature in these books, ${ }^{7}$ as Janzen did, for instance, ${ }^{8}$ but this chapter will do this the other way around, taking Leviticus as point of reference.

This overview will eventually lead us to the narratives about Hezekiah and Josiah, and it will also lead us to considering issues of clean and unclean, concepts which for some reason virtually feature only in the stories about these two

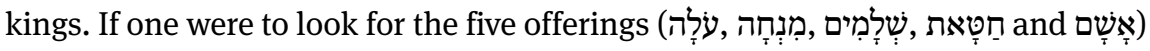
mentioned in Leviticus 1-7 then one finds the situation as discussed below.

\section{A brief overview of Levitical sacrifices in Chronicles}

The first type of sacrifice found in the book of Leviticus is the על על usually translated as "burnt offering." It is regarded as one of the oldest and most prevalent sacrifices in the Old Testament. ${ }^{9}$ The whole sacrificial offering was burnt and

7 One could, for instance, start by looking at how the verb זבח is used. The verb is found in 1 Chronicles 15:26; 21:28; 29:21; 2 Chronicles 5:6; 7:4, 5; 11:16; 15:11; 18:2; 28:4, 23(x2); 30:22; 33:16, 17,$22 ; 34: 4$. Of these the ones in italics do not mention any specific kind of sacrifice, but in other

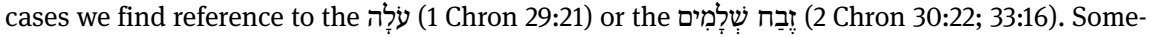
times the verb is used to describe the wrong kind of sacrifices as in 2 Chronicles 28:4, 23; 33:17, 22; 34:4. In 2 Chronicles 18:2 the verb actually refers to "slaughter" and not "sacrifice". We also find the very general term (2 2 Chron 7:4, 5) as object of the verb. In Leviticus the term would usually be used in a construct relation with 17:16, 17; 23:37, which are all texts of the Holiness Code.

8 David Janzen, The Social Meanings, 209-42. In his discussion of sacrifice in Chronicles he focuses on two kinds of sacrifices namely "ad hoc" and "regular". Janzen also focuses more on 1 Chronicles 23-27 whereas the path taken in the present contribution rather leads to the narratives about Hezekiah and Josiah.

9 See overviews in Hieke, Levitikus 1-15, 82-4; James W. Watts, Leviticus 1-10, HCOT (Leuven: Peeters, 2013), 172-5; Jacob Milgrom, Leviticus 1-16: A New Translation with Introduction and Commentary, AB 3 (New Haven: Yale University Press, 2009; repr., New York: Doubleday, 1991), $172-7$. 
nothing was left over. The עלָדה is found in Leviticus 1, but also in many other famous stories in the OT; for instance, in the Akedah Isaac is saved from becoming an על עלה But Jephthah's daughter is not so fortunate in Judges $11{ }^{10}$ The first big disagreement between Samuel and Saul in 1 Samuel 13 was because Saul presented

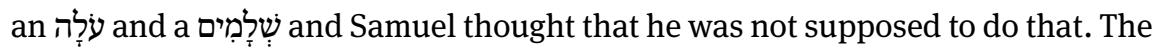
עלָָה is found in many other texts, including 43 occurrences in the book of Chronicles. ${ }^{11}$ The first occurrence of the term tells us something of the Chronicler's view of priesthood:

\begin{tabular}{|c|c|}
\hline 1 Chronicles 6:34 (BHS SESB 2.0) & 1 Chronicles 6:49 (NRSV) \\
\hline 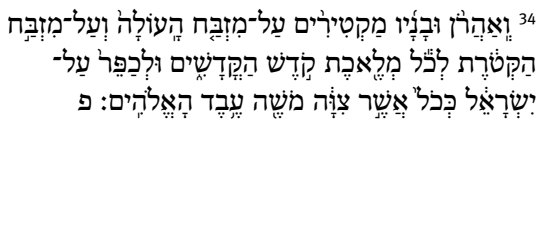 & $\begin{array}{l}{ }^{49} \text { But Aaron and his sons made offerings on } \\
\text { the altar of burnt offering and on the altar of } \\
\text { incense, doing all the work of the most holy } \\
\text { place, to make atonement for Israel, according } \\
\text { to all that Moses the servant of God had com- } \\
\text { manded. }\end{array}$ \\
\hline
\end{tabular}

This description follows after we had been told about which Levites were supposed to make music in the tabernacle. This text acknowledges that there are two altars in the sanctuary, and it is the job of Aaron's sons to burn sacrifices on them: the outside altar of the על על and the inside altar of incense. These are the same terms used in Exodus 30 and, for instance, in Leviticus 4 (but they do not occur in Lev 16). ${ }^{12}$ It is also clear that the vocation of the sons of Aaron is to bring about reconciliation (כפר). This text sounds like a good summary of the sacrificial cult as portrayed by the authors of Leviticus. ${ }^{13}$ In Leviticus the verb כפר is usually used to describe the result of a sacrificial process which leads to reconciliation or atonement. ${ }^{14}$ Usually, the priest is the subject of the verb. ${ }^{15}$ On one occasion (Lev 17:11)

10 Erhard S. Gerstenberger, Das 3. Buch Mose. Leviticus, ATD 6 (Göttingen: Vandenhoeck \& Ruprecht, 1993), 22-3 speculates that the עלדה might have originated with human sacrifice.

111 Chronicles 6:34; 16:1, 2, 40 (x2); 21:23, 24, 26 (x2), 29; 22:1; 23:31; 29:21; 2 Chronicles 1:6; 2:3; 4:6; 7:1, 7 (x2); 8:12; 13:11; 23:18; 24:14; 29:7, 18, 24, 27 (x2), 28, 31, 32 (x2), 34, 35 (x2); 30:15; 31:2, 3 (x3); 35:12, 14, 16.

12 For a detailed discussion of this issue, see Nihan, From Priestly Torah, 161-4. Nihan argues that Leviticus 4 and Exodus 30 belong to a younger P layer than, for instance, most of Leviticus 16 and Exodus 30. Or see the more recent overview in Julia Rhyder, The Holiness Legislation and Cult Centralization in the Persian Period (PhD Thesis, University of Lausanne, 2018), 32-5. She also engages with the text-critical debate.

13 See Knoppers "The Relationship,” 329.

14 I will use both "reconciliation" and "atonement" as translations of כפר and thus as synonyms. 15 E.g. Leviticus 4:20, 26, 31, 35; 5:6, 10, 13, 16, 18, 26 etc. 
blood is the subject. Leviticus 1:4 says that the offerer must put his hand on the head of the עלָָ עלה so that it can bring about reconciliation (כפר) for the addressee.

In the rest of Chronicles the עלָָ עלה is found in combination with other sacrifices,

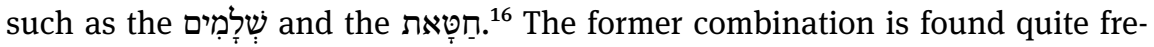
quently in the Old Testament, as mentioned before, but it is not common in Levit-

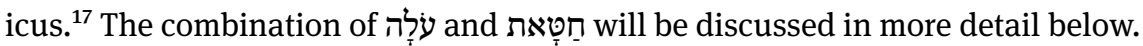

The second offering found in Leviticus, chapter 2, is the מִנְָָה, which in Leviticus usually means "grain offering". The noun occurs 11 times in Chronicles, but in most of these cases it means a gift or tribute, which is the more basic meaning of the noun, compared to the more technical sacrificial term found in Leviticus $2{ }^{18}$ On three occasions we do read of the grain offering specifically. In 1 Chronicles 21:23 Ornan presents cattle as burnt offerings, and wood, and wheat for a grain offering to David. In 1 Chronicles 23:29 David gives the duty of taking care of the rows of bread and the choice flower for the grain offering to the Levites. Many of the terms which occur in 1 Chronicles 23:29 are found in Leviticus, where they are used to describe the duties of the Aaronides. ${ }^{19}$ Levites "trespassing" into cultic territory reserved for priests in Leviticus seems to be an essential aspect of the portrayal of the cult in Chronicles. One should also add that despite the name of the book, Leviticus is not really interested in Levites. They, or their cities, to be exact, feature only in a few verses in chapter 25 (vv. 32-33). This issue of "promoted" Levites is a general point of debate amongst scholars of Chronicles. ${ }^{20}$ Knoppers, after discussing the role of Levites in 1 Chronicles 23:28-32, puts it as follows: ${ }^{21}$

The Chronicler draws on Priestly terminology, but he does so to expand levitical responsibilities and to blur some of the clear distinctions advanced by the Priestly writers and defended by Ezekiel.

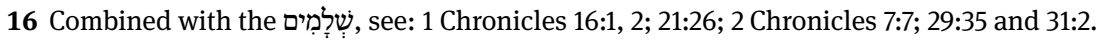

17 In Leviticus 4:26 and 35 the text says that the fat of the nָָָׁאת should be treated like the fat of the שִלְמִ but the two are not used in the same ritual. These two sacrifices are also listed together with the other three sacrifices in 7:37 in a concluding verse to that chapter. Both do feature in Leviticus 9 when Aaron and his sons are inaugurated, but so is the מִנְחָה מדלה

18 David Clines, “מִֹזְה," DCH 5:350-1.

19 I am referring to the following words: 1) מַעְרֶ, which refers to the rows in which the bread is arranged, is found in Leviticus 24: 6 and 7. The same goes for the Hophal participle of the verb מַחְַבַת or "mix" which also occurs in the verses from Leviticus just mentioned. Another term is or baking tray on which flat breads were baked, found in Leviticus 2:5; 6:14 and 7:9. Then there is רָרקיק or "flat bread" found in Leviticus 2:4; 7:12 and 8:26.

20 See Gary N. Knoppers, "Hierodules, Priests, or Janitors? The Levites in Chronicles and the History of the Israelite Priesthood," JBL 118/1 (1999):49-72, especially pages 51-3, where he provides an overview of past debates.

21 Knoppers, “Hierodules, Priests, or Janitors?”, 64. 
Although I cannot comment on Ezekiel, his argument about the expansion of Levitical responsibilities seems sound. We will return to this topic below. To return to the issue of the in 2 Chronicles 7:7, Solomon consecrated the middle court

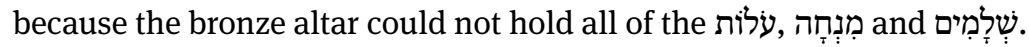

We read here of a מִנזָחה a עלות a and also the third offering found in Leviti-

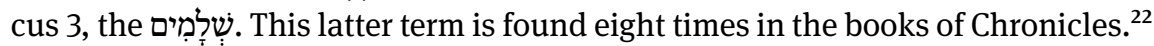
It is usually used in combination with the עלדלה. Thus, David sacrifices both in 1 Chronicles 16:1-2 and also in 1 Chronicles 21:26 after he received them as gifts from (the just mentioned) Ornan. As mentioned before, this combination of עלָה and שִלְמִים is quite common in the narratives of the Old Testament, as in 1 Samuel 13 , for instance, where Saul gets into trouble for sacrificing them, a story that the Chronicler does not narrate.

When Hezekiah celebrates the Passover, we read that in 2 Chronicles 30:22 the people ate of the שִלְמִים, but earlier in the chapter the priests did also bring some על עלות Both offerings are thus used on the same occasion. These are indeed strange sacrifices as Exodus 12 - the basic priestly instruction on the refer to them at Passover. The same is true of Leviticus 23. Numbers 28 presents

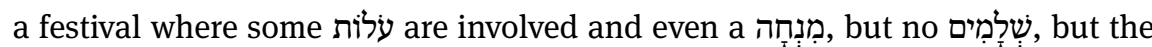
are actually associated with the festival of unleavened bread. This is despite 2 Chronicles 30:16 stating that the sacrifice was executed "according to the law of Moses the man of God." In light of this tension, Japhet argues that "the Chronicler did not refer to the written word as it stands, but rather to the way it was understood and interpreted, either by him or at his time ..."23

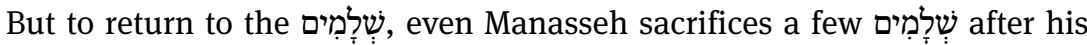

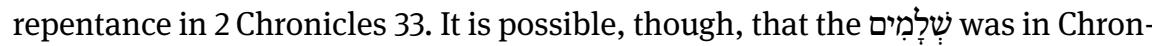
icles, just as in Leviticus, the main sacrifice that provided food for the table of the person bringing the offering. ${ }^{24}$

In Leviticus the sacrifices just discussed would usually be called "voluntary", while the sacrifices found in chapters 4 and 5 are "required". ${ }^{25}$ These latter sacri-

22 See 1 Chronicles 16:1, 2; 21:26; 2 Chronicles 7:7, 29:35; 30:22; 31:2 and 33:16. All the references

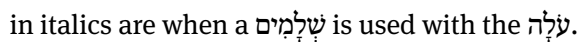

23 Sara Japhet, I \& II Chronicles: A Commentary, OTL (London: SCM Press, 1993), 950.

24 Or, that is the impression one gets from a text such as 2 Chronicles 30:22. This is the only case where eating by the people is explicitly mentioned. In Leviticus the שָלִמִים is often regarded as the sacrifice which provides food for the table. See the discussion in Milgrom, Leviticus 1-16, 217-25, but especially 221. Also, Hieke, Levitikus 1-15, 95, who translates this sacrifice as Heilsgemeinschaftsopfer. As he puts it: "Die Gemeinschaft wird auch durch das gemeinsame Essen betont." 25 See, for instance, the overview of sacrifices found in Frank H. Gorman "Sacrifices and offerings," NIDB 5:23-6. 
fices are often regarded as later exilic or post-exilic developments with their roots in the pre-exilic period. ${ }^{26}$ They are the translated as sin offering or purification offering (but חָטָּאת is also the word for sin), and the אָשָָ is translated as guilt offering or restitution offering. The אָָָָ offering is absent from Chronicles, but one does find a female version of the noun אַשְָׁ which means guilt. ${ }^{27}$ Although one finds the word חַָָָ frequently in Chronicles, it usually refers to sin. But the sin or purification offering is mentioned on one occasion and that is during Hezekiah's restoration of temple worship.

In the rest of this essay, we will specifically focus on the narratives regarding Hezekiah and Josiah, which some scholars regard as a "literary climax" of sorts. ${ }^{28}$

\section{Hezekiah's reform}

The Chronicler tells his story about the reform of Hezekiah over three chapters. For Ralf W. Klein, these chapters all go back to 2 Kings 18:4. ${ }^{29}$ Thus, one verse in the Former Prophets becomes three chapters in which the Chronicler tells us about "the Purification of the Temple and the Restoration of the Cult" in chapter 29 and then in 30 about "The Passover of Hezekiah". The Chronicler concludes this long tale about Hezekiah's reforms with chapter 31 on “the completion of Hezekiah's Cultic Reforms; Provisions for Collection and Distributing Contributions to the Priests and Levites". ${ }^{30}$ We have already referred to the Passover as described in chapter 30, and we will revisit that chapter in this part, but will focus especially on chapter 29. The חַָָָ is mentioned for the first time in 29:21 and then again in verses 23 and 24 . Before we get to these verses, we need to talk through the first 20 verses of chapter 29, which tell how the temple was "cleaned" or "cleansed" before the sacrifices were presented. I am using verbs like "clean" and "cleanse" (the ritualised version of "clean") rather loosely at this stage, but my discussion of them in this chapter will attempt to clarify their meaning.

26 For a detailed discussion of this rather complex debate, see Nihan, From Priestly Torah, 166-

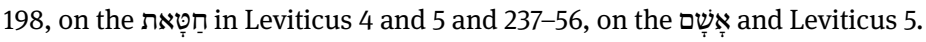

27 See Clines, “אָשְׁ," DCH 1:416-7.

28 Louis C. Jonker, "Holiness and the Levites: Some Relections on the Relationship between Chronicles and Pentateuchal Traditions," in Eigensinn und Entstehung der Hebräischen Bibel. Erhard Blum zum siebzigsten Geburtstag, eds. Joachim J. Krause, Wolfgang Oswald and Kristin Weingart (Tübingen: Mohr Siebeck 2000): 457-76, here 473.

29 Ralph W. Klein, 2 Chronicles: A Commentary, Hermeneia (Minneapolis, MN: Fortress Press, 2012), 412.

30 Headings from Klein, 2 Chronicles, 409-56. 
In the first part of the chapter we read how the temple which was closed in the time of Ahaz (only mentioned in v. 19) has now been reopened by Hezekiah, but it first needs to be "cleansed". Hezekiah calls the priests and Levites together and the give a brief speech (vv. 5-11). ${ }^{31}$ Hezekiah instructs them first to sanctify themselves (Hitp קדש a (קדש Pi) and sanctify "the house of YHWH the God of your fathers" and remove the נדָָּה (NRSV "filth", NKJV "rubbish") from the sanctuary. Verses 12-14 provide us with a list of the Levites who participated. In verse 15 they

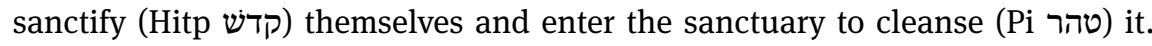
Then in the next verse (v. 16) there seems to be a division of labour between priests and Levites, with the former going into the "inner part" (פְּנִימָה) of the "house

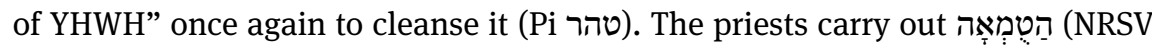
"unclean things") to the court, and the Levites then carry it to Wadi Kidron. This whole process lasted sixteen days (v. 17), and when they finished, they reported to the king (v. 18) that they had indeed cleansed (Pi טהר) the house of YHWH and that all the utensils have been sanctified (Pi (קדש As). ${ }^{32}$ As Klein points out, there is no mention here of the inner altar or ten golden lampstands, but these are probably included with the utensils (הַכָּלִים). ${ }^{33}$

It is only after the Levites and priests had cleansed the temple that we read of a nַ male goats presumably presented as חָָּאת Y. Yet, if one also reads verses 22 to 24 , it seems that only the seven male goats were חַטָאת, whereas the other sacrifices were actually עלוֹ. Verse 22 describes how the bulls, rams and lambs were slaughtered

31 There is a discrepancy here in that the king assembles both groups in verse 4, but then in verse 5 he only speaks to the Levites. Japhet, I \& II Chronicles, 917, argues that "Levites" has a broader meaning here, including "all the members of the tribe of Levi, constituting the clergy at large.” Raymond B. Dillard. 2 Chronicles, WBC 15 (Waco, TX: Word Books, 1987), 233, argues that either the text is highlighting the Levites, or the term includes both groups (as with Japhet), but also thinks that there is clearly some rivalry going on between the two groups. See also Klein, 2 Chronicles, 413, who presents a similar argument to that of Japhet. Jonker, Defining All-Israel, 264, states that verse 12 shows that only the Levites (excluding the priests) respond. The question would then be why do the priests participate in verse 16 ? They actually went into the inner part of the temple.

32 Japhet, I\& II Chronicles, 922, thinks that “'purify' denotes the cleansing, the deliverance of the Temple from a state of 'pollution', the removal of an essentially negative condition; 'sanctify' or 'hallow' goes beyond 'purity' and brings the Temple to the elevated state of sanctity." Although this interpretation makes sense from a strictly semantic perspective, it is not clear that the Chronicler really distinguished between the two processes. It sounds as if the priests going into the "inner part" to purify and the description of starting to sanctify on the first of the month in verse 17 refer to the same event, which means that the Chronicler uses the two terms as synonyms.

33 Klein, 2 Chronicles, 420. 
and the blood dashed by the priests. ${ }^{34}$ Then verse 23 singles out the male goats

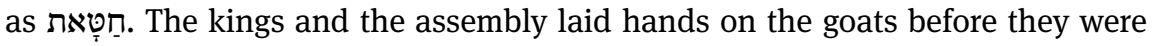
slaughtered by the priests. It seems that there are two kinds of sacrifices performed here and if one takes into account that verse 24 concludes by stating that the king

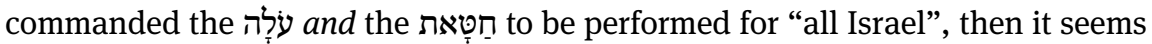

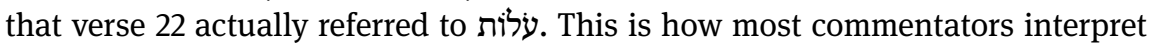
these verses. ${ }^{35}$ With regard to the חָטָׁאת of verse 23 , it is spelled out that the priests used the blood on the altar to bring about reconciliation (כפר) for all of Israel in verse 24. This is only the second time that כפר is used after 1 Chronicles 6:34 (BHS). ${ }^{36}$

The history of the חַטָָאת offering is complex and cannot be discussed here in detail. One could mention, though, that some scholars such as Jacob Milgrom and Christophe Nihan would argue that there are indeed two kinds of offering. ${ }^{37}$ Here, with only one occurrence, there seems to be one kind only and the חַטָטאת is brought only after the cleansing or sanctifying of the temple in the first 20 verses of the chapter. Another issue is how to translate the term; the options are the more traditional "sin offering" or as a "purification offering", a translation which seems to be more dominant in recent years. ${ }^{38}$

34 An issue explored by most commentaries here is who slaughtered these burnt offerings. For Japhet, I \& II Chronicles, 926, the "they" refers to laymen. Dillard, 2 Chronicles, 236, and Klein, 2 Chronicles, 421, both agree that in the light the Leviticus 1:4, 5 it could indeed be the laymen who did the slaughtering, but both allow for some ambiguity in the text.

35 Japhet, I \& II Chronicles, 925; Klein, 2 Chronicles, 421; Dillard, 2 Chronicles, 235; Milgrom, Leviticus 1-16, 285. See also Rolf Rendtorff, "Chronicles and the Priestly Torah," in Texts, Temples, and Traditions: A Tribute to Menahem Haran, eds. Michael V. Fox, Victor A. Hurowitz, Avi Hurvitz, Michael L. Klein, Baruch J. Schwartz, and Nili Shupak (Winona Lake, IN: Eisenbrauns; 1996), 259-66, here 263.

36 A fascinating debate is why the change from "for Judah" in verse 21 to "for all Israel" in verse 24. For most scholars this is clear evidence of a more inclusive approach present in the two books of Chronicles. The mention of "all Israel" here also paves the way for the manner in which the Passover is celebrated in the next chapter with Northerners also invited. See discussions by Milgrom, Leviticus 1-16, 285-6; Klein, 2 Chronicles, 422; Dillard, 2 Chronicles, 236. For a more detailed discussion see Jonker, Defining All-Israel, 151-90.

37 Milgrom, Leviticus 1-16, 253-91; Nihan, From Priestly Torah, 179-186. Or, originally, see Jacob Milgrom, “Two Kinds of hatțât," VT 26/3 (1976):333-7.

38 See Milgrom, Leviticus 1-16, 253-8, for a detailed discussion, but already going back to Jacob Milgrom, "Sin-offering or purification offering?" VT 21/2 (1971):237-9. For further discussions on how to translate the term see, for instance, Hieke, Levitikus 1-15, 88-92, who opts for a more traditional translation of "Entsündigungopfer”, or Watts, Leviticus 1-10, 302-16, who would also prefer to stick to the traditional translation of "sin offering". Other scholars such as Gorman, "Sacrifices and offerings," 25, Jay Sklar, Leviticus: An Introduction and Commentary, Tyndale (Downers Grove, IL: Inter-Varsity Press, 2013), 107-8; Gordon J. Wenham, The Book of Leviticus, 
If one compares this elaborate ritual described in 2 Chronicles 29 with chapters 4, 5 and 16 of Leviticus, where the חָטָָאת is mostly found in Leviticus, ${ }^{39}$ then it is important to note that there is no ritual in Leviticus prescribed for a scenario after the temple has been closed. There could not be, because Leviticus works within the fiction of Sinai and the tabernacle. As Japhet rightly points out: 40 "The ceremony as described is different from anything prescribed or described elsewhere in the Bible."

The Chronicler could, however, have drawn very loosely from Leviticus 16, which does describe the yearly ritual cleansing of the sanctuary. ${ }^{41}$ As Benedikt Jürgens argues, the purpose of the use of the חַטָאת in Leviticus 16 is to facilitate a yearly return to the "Zustand des Heiligtums" achieved originally with the consecration of the sanctuary in Leviticus 8-9.42 Leviticus 16 uses the combination of

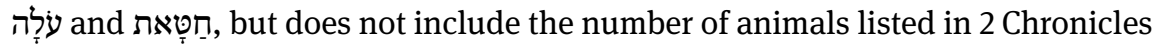
29:21. There is no mention of a male sheep in Leviticus 16 and a bull is used as a

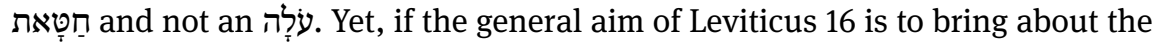
"permanent restitution of Yahweh's Presence in Israel", ${ }^{43}$ then it seems like a suitable text to draw from. As Gorman puts it with regard to Leviticus 16:44

The ritual clearly reflects the structure of a community rite of passage. More specifically, it reflects community passage to a renewed and reordered state of existence. Thus, it must be seen primarily as a ritual of restoration - it serves to restore the community to its prescribed and founded state.

NICOT (Grand Rapids, MI: Eerdmans, 1979), 88-9, follow Milgrom in this regard. It is also worth noting that not all commentators on Chronicles used here follow Milgrom. Japhet, I \& II Chronicles, 925 and Dillard, 2 Chronicles, 235 do not, whereas Klein, 2 Chronicles, 421 does.

39 חָטָטָת is found in the following instances in Leviticus: 4:3(x2), 8, 14(x2), 20, 21, 23, 24, 25, 26, 28(x2), 29(x2), 32, 33(x2), 34, 35; 5:6(x3), 7, 8, 9(x2), 10, 11, 12, 13; 6:10, 18, 19, 23; 7:7, 37; 8:2, 14, 15; $9: 2,3,7,8,10,15,22 ; 10: 16,17,19 ; 12: 6,8 ; 14: 13,19,22,31 ; 15: 15,30 ; 16: 3,5,6,9,11,15,16,21,25,27$, 30,$34 ; 19: 22(\mathrm{x} 2) ; 23: 19 ; 26: 18,21,24$ and 28 . Of these, the following refer to sin and thus not the sacrifice: 4:3, 14, 23, 26, 28(x2), 35; 5:6, 10, 13; 16:16, 21, 30, 34; 19:22(x2); 26:18, 21, 24 and 28. In some cases you have the two meanings in one verse such as 4:3, 14 and 5:6.

40 Japhet, I\& II Chronicles, 924.

41 McKenzie, 1-2 Chronicles, 341, also thinks the chapter is reminiscent of the "Day of Atonement”.

42 Benedikt Jürgens, Heiligkeit und Versöhnung. Levitikus 16 in seinem literarischen Kontext. HBS 28 (Freiburg: Herder, 2001), 342.

43 Nihan, From Priestly Torah, 370-1. The heading from Nihan does not refer to any historical context, though, but to the restoration of the new order created by Leviticus 8-9 "every time it is significantly transgressed." This new order is threatened by ritual impurities and moral faults.

44 Frank H. Gorman, Ideology of Ritual: Space, Time and Status in the Priestly Theology, JSOTS 91 (Sheffield: Sheffield Academic Press, 1990), 61. 
In both Leviticus 16 and 2 Chronicles 29:24 we read that atonement is brought

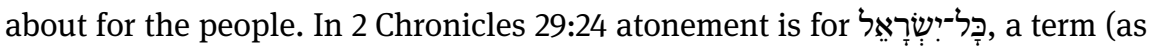
indicated above) which often leads to debates about inclusivity. The use of the verb כפר in Leviticus 16 is a much more complex issue, but it is used for both people and the sanctuary..$^{45}$ Even though the Chronicler did not mention the temple itself,

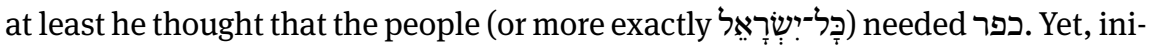

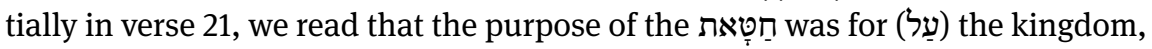

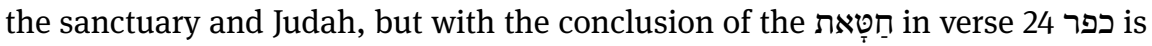

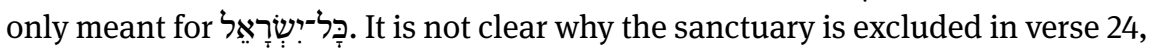
but in the light of verse 21 I hesitate to argue that the Chronicler thought that only

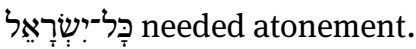

We are again reminded of the job of the priests and that is to play a crucial role in slaughtering the חָטָָאת and bringing about atonement for Israel. This links up with 1 Chronicles 6:49. Yet the role played here by the Levites is something not found in Leviticus and it is another case of "promoted" Levites. ${ }^{46}$

There is another ritual in 2 Chronicles 29 which is also (at least at first glance) reminiscent of Leviticus 16 and other texts in Leviticus, and that is the king and the assembly laying their hands on the male goats for the slaughtered them. In Leviticus this act is performed in 1:4 by the person who

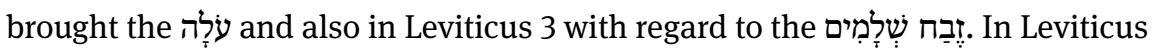
4 the same is true of the חָטָאת . On five occasions (vv. 4, 15, 24, 29 and 33) one

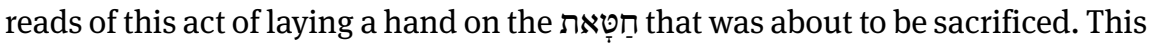
action is also found in Leviticus 8 with the ordination of the priests, when Aaron and his sons lay hands on each of the three sacrifices found in that chapter. Here

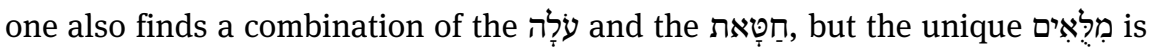
added. Also, in Leviticus 16:21 Aaron lays his hands on the go-away goat, which is called a חַטָׁאת, but it does not get slaughtered. But this ritual is different in the sense that it is usually regarded as an elimination ritual and is clearly not a

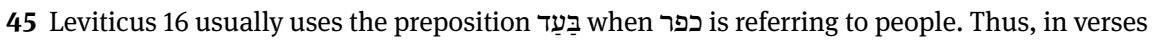
6, 11 and 17 the is used for Aaron and his house, but in verse 24 the עָָָׁאת is used for Aaron and the people. When applied to the sanctuary or other parts of it, one finds other prepositions. In verse 10, עַ is used in reference to the altar and the same goes for the sanctuary in verse 16, but in verses 17 and 27 is used in reference to the sanctuary. Then in the last few verses of the chapter עַ suddenly gets used with reference to people. Verses 29-34a are often regarded as a later layer in the text. See Thomas Hieke, Levitikus 16-27, HTKAT (Freiburg: Herder, 2014), 569-70. For a discussion of the use of the different prepositions see Milgrom, Leviticus 1-16, 255-6.

46 Jonker, “Holiness and the Levites," 457-76. Or for a more detailed discussion Jonker, Defining All-Israel, 263-7. 
sacrifice. ${ }^{47}$ What exactly this act means has been debated extensively regarding Leviticus, ${ }^{48}$ but with regard to Chronicles most of the commentators engaged with in this chapter are not really interested in this debate. ${ }^{49}$ One cannot blame them, since the Chronicler did not tell us whether it was with one hand or two hands. The latter is stipulated in Leviticus 16:21.

Apart from Leviticus 16 and other texts where the חָטָָת is mentioned in Leviticus, the Chronicler could also have drawn from other texts in the book of Numbers, or Ezekiel. ${ }^{50}$ It is furthermore important to note that the number of animals referred to in this text is astounding and there is nothing in Leviticus that is similar, or in the Hebrew Bible for that matter. Rendtorff thinks that the number of animals is clearly "a product of the Chronicler's imagination." ${ }^{51}$ Rendtorff also argues that the Chronicler was not really interested in the חָטָאת as such, as it is only mentioned at this point in the story. ${ }^{52}$ In response to this argument one could argue that the חָטָָאת is mentioned at a very crucial junction in the narrative of the Chronicler, if not even as some kind of "literary climax."

About the reference to חָטָאאת here, one could say that despite many differences, the Chronicler at least understood that a ritual solution would be necessary before the temple could be used again. This kind of thinking is not that far removed from priestly thinking and if one were to look for other examples (apart from Leviticus 16) of where the עלָָָׁאת and are combined, they often occur

47 For a more recent engagement with Leviticus 16, see Christian A. Eberhart, "To Atone or Not to Atone: Remarks on the Day of Atonement Rituals According to Leviticus 16 and the Meaning of Atonement," in Sacrifice, Cult, and Atonement in Early Judaism and Christianity: Constituents and Critique, eds. Henrietta L. Wiley and Christian A. Eberhart (Atlanta, GA: SBL Press, 2017), 197-232. 48 See the overview in Jürgens, Heiligkeit und Versöhnung, 229-31 or Milgrom, Leviticus 1-16, $150-3$.

49 Or, that is how I interpret the virtual absence of discussion. Japhet, I \& II Chronicles, 926, refers to this ritual in Leviticus 1:4 and 4:15, but does not engage with its meaning. Dillard, 2 Chronicles, 235-6, offers no discussion. Klein, 2 Chronicles, 421, opts for one of the possible interpretations, namely identifying with the victims, which is one that Milgrom, Leviticus 1-16, 151, rejects.

50 Japhet, I \& II Chronicles, 925, refers to Numbers 7:88, where "[t]his particular combination of sacrifices - bulls, rams and lambs for burnt offering and he-goats for sin-offering - is prescribed ...” In Numbers 7, this event only happens over one day, though. She also points out that the "additional sacrifices of the holidays" in Numbers 28 and 29 are similar and that these combinations of animals are also mentioned in Ezra 6:17 and 8:35 with the dedication of the second temple. Dillard, 2 Chronicles, 236, argues that the "inclusion of the sin offerings finds its closest analog in the sin offerings mentioned in Ezekiel as part of the cleansing of the altar and sanctuary." He then refers to chapters 43 to 45 . He does not provide any detailed support for his statement.

51 Rendtorff, "Chronicles and the Priestly Torah," 263.

52 Rendtorff, "Chronicles and the Priestly Torah," 265. 
in chapters where a ritual solution is provided for impurity, namely Leviticus 12 to 15 . They are combined in Leviticus 12:6 when a woman is finally cleansed after giving birth. They are also combined (with an מִנָָָָה 14 in the final phase of the ritual for the cleansing of a person who had צִרֵַת They are combined in 15:15 and 30 as part of a ritual in response to an irregular discharge in a man, or of a woman who suffers from an irregular זil. Thus, one

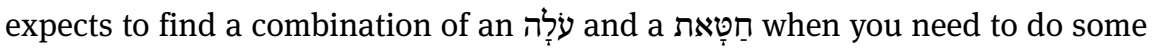
kind of ritual cleansing. ${ }^{53}$

We need to take a closer look at how 'impurity' language is used in the first half of 2 Chronicles 29. This language in the earlier part of the chapter stands out for somebody who is more familiar with Leviticus, and this part of the chapter describes what takes place before the sacrifices are presented. It is indicated above that the verb טהר (Piel) is used in verses 15, 16 and 18. In verses 15 and 16 it refers to the Levites who will "cleanse" the temple, and in verse 16 to priests who go into the house of the lord to "cleanse" it. What does cleansing actually mean here? Basically, the priests are taking unclean things from the temple, which are also described with terms usually associated with impurity language. In verse 5 the king had already said that the נדָָּה needs to be taken from (Hif of יצאי) the temple and in verse 16 the priests go in to remove (Hif of יטמאָה from the temple. In Leviticus טְמְ usually refers to impurities associated with biological processes such as menstruation or discharge from a woman $(15: 25 ; 18: 19)$ or a man (15:3) or צִ צִרָָּה ${ }^{54}$ usually refers to menstruation in Leviticus and the usage of the term is very odd here. ${ }^{55}$ Quite a few scholars have recently studied this term, often drawing from the perspective of gender studies. Thus Elizabeth W. Goldstein discusses three stages in the development of the meaning of the term

53 See the discussion in Nihan, From Priestly Torah, 169-70. One of the questions in this debate is whether the clearly older עלָָ yalways had an atoning function. Nihan would say yes. With regard

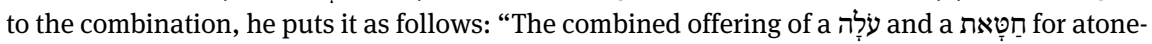
ment is further found in Num 15:24-25; it also consistently occurs in the context of purification rites from a major source of pollution, see Lev 12:6-7a, 8; 15:15, 30, as well as Num 6:11; 8:12.”

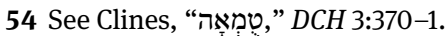

55 In Leviticus the word is found in: 12:2, 5; 15:19, 20, 24, 25(x3), 26, 33; $18: 19$ and 20:21. The last example is an exception as the word is used to express a general feeling of disgust, similarly

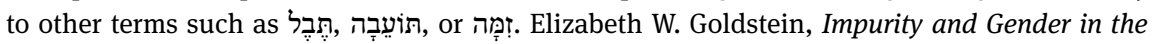
Hebrew Bible. (New York: Lexington Books, 2015), 58 regards this latter occurrence as a gloss. As a member of the Kaufmann school, which dates the Holiness Code to the late pre-exilic period, she has no choice, because otherwise this meaning will not fit into the three phases she identifies in the development of the term, as explained in the next footnote. 
with the usage here presenting the last phase. ${ }^{56}$ Most of these scholars agree that in 2 Chronicles 29:5 the term no longer means menstruation, but refers to objects in the temple which made it unclean and therefore the temple needed cleansing from these objects and their polluting effect. ${ }^{57}$ What were these objects?

Scholars usually refer to the next chapter on the Passover, or the even later story of Josiah's reform and the earlier one of Asa to answer the question. ${ }^{58}$ These objects were illegitimate and associated with other gods. Incidentally, one also finds impurity language in the two following stories of Hezekiah's Passover and Josiah's reform, which we will now discuss briefly.

\section{More stories about impurity}

Although references to sacrifices and offerings are not so prevalent in the rest of 2 Chronicles and the חַטָּאת is never mentioned again, one does find some ref-

56 Goldstein, Impurity and Gender, 54-58. The term initially only had the meaning of menstruation, which implies that it is a state which makes you unclean. The second stage was when the term gained a more figurative meaning, which presented revulsion as found in Lamentations 1:17 and Isaiah 30:22. The term now expresses something of the shunning of the menstruant which is applied to Jerusalem or images of idols which are to be shunned more or less like the proverbial "hot potato." For Goldstein these two phases are followed by a third, which she calls a "semantic broadening" in the Second Temple Period and now it refers to "sins threatening the fabric of the community" and in this regard she uses 2 Chronicles 29:5 as an example. In this period the word can either mean menstruation or this new broadened meaning expressing some kind of sin. See also the overview in Eve L. Feinstein, Sexual Pollution in the Hebrew Bible (Oxford: Oxford University Press, 2014), 181-3, who responds to Goldstein's argument (citing her PhD from 2010) and does not find all aspects convincing. For a further discussion of the term see Dorothea Erbele-Küster, Body, Gender and Purity in Leviticus 12 and 15, (New York: Bloomsbury, 2017), $117-37$.

57 Thus Feinstein, Sexual pollution, 182 sketches this usage "to denote any type of pollution, with no particular connection to menstruation”. Erbele-Küster, Body, Gender and Purity, 122, describes this usage of the term as "pejorative and polemical" and for her becomes "a literary indication of what is outside the system." See also the discussion in Christophe Nihan, "Deuteronomic alignment in Chronicles: Royal Reforms and the Elimination of Cultic Objects," in Writing, Rewriting, and Overwriting in the Books of Deuteronomy and the Former Prophets: Essay in honour of Cynthia Edenburg, eds. Römer, T., Sergi, O. and Koch, I. (Leuven: Peeters, 2019): 309-36, here 322.

58 Klein, 2 Chronicles, 419 and Nihan, "Deuteronomic Alignment," 322 mention the altars destroyed in 30:14. Klein refers to both the reforms of Josiah which burned "illegitimate cult objects" or the burning of the image of Asherah during the reign of Asa. 
erences to purity language. ${ }^{59}$ Whereas the cases just discussed seem closer to priestly thinking, things now change.

In 2 Chronicles 30:18 we read of a multitude of people who came to Hezekiah's Passover who did not cleanse (Hitpael of טהר) themselves. Most commentators seem unsure about what could have caused the people to be unclean. ${ }^{60}$ In Leviticus, this stem of the verb is found a lot in chapter 14 , where it is always a

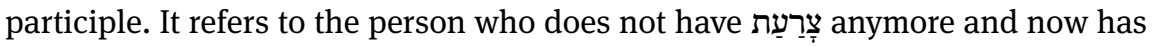
to go through the elaborate cleansing process described in that chapter. It is often translated with "the one who is to be cleansed." The text of the Chronicler is not clear on which rituals these people in 2 Chronicles 30 were supposed to perform, but verse 17 makes it clear that Levites had to offer the Passover lamb for those who were not clean. Verse 18 also says that Hezekiah prayed for them and the "good Lord pardoned all (NRSV)." Here the verb כפר is used again. In Leviticus that verb always follows a sacrifice, yet here one finds that a prayer by the king does the trick. This usage of כפר in Hezekiah's prayer is also in tension with 1 Chronicles 6:49, cited earlier, where the Aaronides are supposed to do the work of the holy place. Here a king can pray and all is forgiven. It is also different from 2 Chronicles 29:24, where it is the priests who slaughter and manipulate the blood to accomplish כפר. Rolf Rendtorff has the following to say on this: ${ }^{61}$

I must confess that I do not understand what the Chronicler means, but in any case this use of kippeer is incompatible with any priestly theology. It is amazing that the Chronicler presents two totally different concepts of kîppēr so close to each other.

For Japhet the fact that the text says that the Lord healed the people in verse 20 makes this "an explicit pronouncement that 'the setting of the heart' is of higher value than ritualistic purity." ${ }^{2}$ This seems to be an explicit critique of the Priestly view of atonement. As Ehud Ben Zvi puts it: ${ }^{63}$

Moreover, in the main case in which matters of ritual purity are saliently raised in Chronicles, namely in the account of Hezekiah's Passover - it is no coincidence that about half of the occurrences of words from the roots טמא טהר occur in this account - the Chronicler

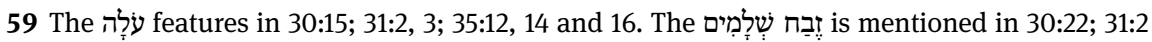
and 33:16.

60 Japhet, I \& II Chronicles, 952, thinks it has to do with "the problem of the pilgrims". She argues that this was a major problem in the "second commonwealth." She also adds that what is presented here as irregular probably happened much more regularly.

61 Rendtorff, "Chronicles and the Priestly Torah," 265.

62 Japhet, I\& II Chronicles, 953.

63 Ben Zvi, "Purity Matters," 41. 
seems to suggest that personal devotion, "setting one's heart," outweighs - although does not eliminate - matters of bodily purity.

But to complete my overview of the verb טהר, it is also found at another incident in 2 Chronicles where we read of the other great love of the Chronicler, namely king Josiah. 2 Chronicles 34 retells the tale of 2 Kings 22. Still, in Chronicles, even before Josiah discovered the book in the temple, he started with a process of cleansing the country of Judah and the city of Jerusalem. In 2 Chronicles 34:3-5 טהר (always in the Piel) is used on two occasions. In verse 3 we read that Josiah started to טהר Judah and Jerusalem from high places, sacred poles and cast images. Verse 5 recounts how Josiah burned the bones of priests on their altars, and thus he purged (טהר) Judah and Jerusalem.

Thus, before Josiah discovered the scroll, he started with this process of purging. In Leviticus only priests can be the subject of the Piel of טהר. Yet now the king is the subject and these actions are not followed by any rituals, but merely a removal of cultic sites belonging to other gods. The text never states that Judah was unclean, but it is presumed, since why would you clean something if it is not unclean? A few verses later, the same verb occurs again in verse 8 , when we read that Josiah purged (טהר) the land. We now learn that after he had cleansed the land and the house, he started to repair the house of the Lord and only after that do they discover the scroll. This kind of thinking is reminiscent of the Holiness Code, especially the parenetic frame, where one reads of the threat that the land could become unclean. ${ }^{64}$ In Leviticus 18:25 and 27 the land will become unclean (Qal of טמא) if (v. 24) the addressees make themselves unclean (Hitpael) by violating any of the taboos mentioned above, since the nations before them became unclean (Nifal) by doing these things. Thus, the Holiness Code refers to the land becoming unclean but does not mention the land becoming clean again like here in Chronicles. The land becoming unclean leads to the land spitting out her inhabitants in Leviticus 18.

In Leviticus the verb טהר is often found in the Piel and in these cases a priest is always the subject of the verb and it usually means that the priest proclaims a person clean who had previously been unclean.$^{65}$ This declaration always follows the performance of certain cleansing rituals in especially Leviticus 12 to 15 where,

64 Eckart Otto, "Innerbiblische Exegese im Heiligkeitsgesetz Levitikus 17-26," in Levitikus als Buch, BBB 119, ed. Heinz-Josef Fabry and Hans-Winfried Jüngling (Bonn: Philo, 1999): 125-96, identifies 18:1-5, 24-30; 19:1-4; 20:7-8, 22-27; 22:8, 31-33; 25:18-19, 38, 42a, 55 and 26:1-2 (172-6) as such instances.

65 Cases of the verb in the Piel: Leviticus 13:6, 13, 17, 23, 28, 34, 37, 59; 14:7, 11, 48. 


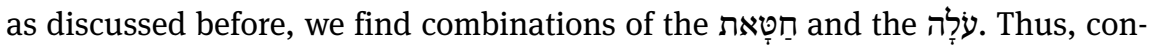
cerning the instruction of צָרעַת in Leviticus 13:6, on the seventh day the priest shall examine a person who suffers from this ailment and if the disease has not spread, he shall declare the person clean. In this case the Piel of טהר is used and if the person did not get better, then the priest would declare him or her unclean, and in that case the Piel of טמא is used. There are many examples of this scattered throughout Leviticus 13, 14 and 16. Chapter 14 deals with cases where a person gets full-blown skin disease but then heals, and performs a very elaborate ritual of cleansing. This ritual includes a lot of washing and laundering, a ritual which involves two birds and more sacrifices involving four of the sacrifices described

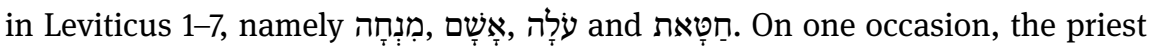
declares the person clean (v. 7) and then three times we read that the person has now become clean (Qal, vv. 8, 9 and 20). Verse 20 follows after all the rituals had been concluded and all the sacrifices had been presented, and "thus the priest shall make atonement on his behalf, and he shall be clean."

The only other two cases of טהר in the Piel are found in Leviticus 16:19 and 30. In verse 19 we read that the blood of the goat of the altar seven times to cleanse it (Piel of טהר) from the impurities of the sons of Israel and to sanctify it. Verse 30 is a much more complicated issue to which we will return later, but many scholars regard this verse as part of the same layer as the Holiness Code. ${ }^{66}$

The point is that this verb (Piel of טהר) is only used in a highly ritualised context with either priests or blood as the subject. In Chronicles, usage of the term seems to be a free for all. In the story of Hezekiah, it is indeed the priests and (promoted) Levites who do the cleansing, but without any sacrifices, as these follow only later. In the story of Josiah, he is the subject of the verb and cleansing is done without any sacrifices.

In all of these cases mentioned above in Leviticus the verb is used to get rid of impurity, but in the examples from the stories of Hezekiah and Josiah it is not so clear what kind of impurity is at stake. This takes us to the debate on the difference between ritual and moral impurity.

66 Thomas Hieke, Levitikus 16-27, 569-70. 


\section{Ritual and moral impurity}

Ritual impurity usually refers to all the impurities indicated in Leviticus 11 to 15 (although chapter 11 and the rules on what to eat and what not is an in-between category). ${ }^{67}$ These impurities are not sins, but are caused by things such as childbirth, skin disease and bodily fluids. They are all part of life and they can be managed with rituals, which is one of the reasons why they are referred to as "ritual impurities." Nihan calls them "physical impurities" because they are "various physical and biological phenomena that affect especially the human body." ${ }^{68}$ It is in this context that the verbs טהר and (especially in the Piel) occur. Yet there are also nouns and adjectives for these terms. These terms occur very rarely in both books of Chronicles. We have already mentioned 2 Chronicles 30:19, where people did not purify themselves, and this presumably refers to ritual impurity. Also, in the next verse, we read of the "cleanliness of the sanctu-

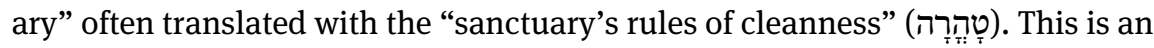
example of the female noun, but the male form (טָהר) appears a few times and is usually used to refer to pure gold, although the male form is also found in $2 \mathrm{Chron-}$ icles 30:17 referring to the Levites who slaughtered the Passover lamb for those who were not clean.$^{69}$ Thus, it seems that this incident with Hezekiah's Passover is the only place where there is a clear reference to ritual impurity. However, the text is silent on any cleansing rituals.

But in Leviticus or more specifically in the Holiness Code (Leviticus 17-26) one also finds what some call "moral" impurities, which are usually regarded as caused by "the transgression of divine laws". ${ }^{70}$ This takes us to something which could be viewed as a sin. In the heart of the argument one finds the idea that sins are defiling, or in other words, lead to what one could call moral contamination. Transgressing a particular law now makes you unclean, not some bodily function.

Jonathan Klawans has elaborated on this distinction extensively and identifies five differences between "ritual" and "moral" defilement: ${ }^{71}$

1. Ritual impurity is not a sin, but moral impurity is. Klawans talks of "grave sin". In the Holiness Code one finds examples of sexual immorality (Lev 18 -

67 See Christophe Nihan, "Forms and Functions of Purity in Leviticus," in Purity and the Forming of Religious Traditions in the Ancient Mediterranean World and Ancient Judaism, eds. Christian Frevel and Christophe Nihan (Leiden: Brill, 2013): 311-67, here 338.

68 Nihan, "Forms and Functions," 321.

69 See 1 Chronicles 28:17; 3:4; 9:7; $13: 11$.

70 Nihan, "Forms and Functions," 339.

71 Jonathan Klawans, Impurity and Sin in Ancient Judaism, (Oxford: Oxford University Press), 26. I am using terms such as "defilement", "impurity" and "pollution" as synonyms. 
when you sleep with another man's wife) and idolatry (Lev 19:31 and 20:1-3), which in Leviticus means turning to wizards and mediums and sacrificing your children to Molech;

2. Ritual impurity is mostly the result of contact, but moral impurity does not entail any contact;

3. Ritual pollution leads to temporary impurity, but moral pollution causes longterm damage. The land spits out the people, as the parenetic frame of the Holiness Code has it, or they are exiled;

4. Ritual impurities are controlled by ritual solutions, but for moral impurity punishment follows. Moral impurity is best to be shunned;

5. In terms of terminology, the root טמא is always used to refer to ritual impurity, but for moral impurity other terms are also used such as found in Leviticus 18 but not in Chronicles at all.

The most crucial point here is that in all of the cases of moral impurity, one finds the verb טמא in the Qal. The verb is used to show that an immoral act made you unclean. But in light of the definition by Klawans, there is no way of undoing this kind of pollution. It leads to exile. The land spits you out. The Piel of the verb טהר is never used to refer to the reversal of moral impurity, with one exception. The one exception is the one already mentioned in Leviticus 16:30, which states atonement takes place to cleanse (Piel of טהר) of sin and that the addressees will be clean (Qal of טהר) before the Lord. This goes against what Klawans is arguing since it is a clear case of removing moral pollution utilising ritual.

To resolve this conundrum, Klawans falls back on diachronic arguments which make this verse part of a later layer that includes the Holiness Code. ${ }^{72}$ The problem is that even if these verses are on the same diachronic level as the Holiness Code, they still contradict Klawans's understanding of the Holiness Code. He argues that references to moral impurity are found in the Holiness Code and that there is no cure for moral impurity in the Holiness Code, yet here it is in Leviticus 16:30. Still, it is only one verse, and apart from this verse, there is no further indication in Leviticus that one could be cleansed of moral sin, only of impurity. And indeed no solution or cleansing process is provided in the Holiness Code for dealing with the sexual sins and idolatry even if employing impurity language.

One should also add that although many scholars have supported Klawans's arguments, many have been critical of his ideas. Just a brief overview of the scholars cited in this paper would provide different views about his work, some pos-

72 Klawans, Impurity and Sin, 172 n. 30 cites Milgrom, Leviticus 1-16, 1064-5 and we have already referred to Hieke, Levitikus 16-27, 569-70. One could also add Nihan, From Priestly Torah, 347-50. 
itive, some negative and some mixed. ${ }^{73}$ A further point of critique would be that it seems that Klawans's categories do not work in the Chronicler's stories about Hezekiah and Josiah. The נְִׁמָָָה 2 in 2 Chronicles 29 referred to foreign cultic objects, which clearly references some kind of idolatry and thus a sin. The same goes for the cultic objects in the story of Josiah. This fits into Klawans's description of moral impurity in the Holiness Code, since there idolatry and sexual sin are described using impurity language. Still, points 2 and 3 of the summary above do not fit these narratives in Chronicles.

Let us start with point 3 first. Klawans says that there is no "cleansing" for moral impurity. Yet in 2 Chronicles 29 the Levites and priests go into the temple to remove all filth and to declare things clean (before any sacrifices). As shown above, the same words refer to ritualised cleansing in Leviticus. Josiah also simply removes the idolatrous objects from the temple and Jerusalem, and that counts as cleansing. Chronicles does not seem to be familiar with the difference between bodily and moral impurity and casually mixes categories. Interestingly, in his response to Klawans, Milgrom says the following about H's use of impurity language: ${ }^{74}$

The truth is that $\mathrm{H}$ has no system! And why should it? $\mathrm{H}$ is not $\mathrm{P} . \mathrm{H}$ is the product of a later school of priests bearing a new agenda (ignored by Klawans). The key to this enigma is that $\mathrm{H}$ has dissolved the terminological precision of $\mathrm{P}$.

With a few adjustments, Milgrom's point seems like a good description of what the Chronicler also did with Priestly views of the cult. Chronicles used Priestly language of 'impurity' but applied it with no terminological precision. The sons of Aaron can bring about כפר, but so can a praying king! Verbs used by Leviticus 1-16 for ritual impurity can describe idolatry. Why not? The Chronicler was certainly not $\mathrm{P}$ and did not pretend to be $\mathrm{P}$ either.

73 Thus, Feinstein, Sexual Pollution, 33 thinks Klawans's distinction is too simple, but Goldstein, Impurity and Gender, 2-5, discusses his work and, despite identifying some shortcomings, builds further on it. Nihan, "Forms and Functions," 342-4, agrees to some extent, but identifies some clear weaknesses with regard to the interpretation of Leviticus 16. Hieke, Levitikus 1-15, 126-9, agrees. Jacob Milgrom, "Systematic Differences in the Priestly Corpus: A Response to Jonathan Klawans,” Revue Biblique 112/3 (2005): 321-9, responded in an article and does not agree. Milgrom actually regards what Klawans calls "moral pollution" as having a metaphorical meaning and simply does not accept Klawans's argument against this metaphorical interpretation. See Klawans, Impurity and Sin, 32-6. For a fairly extensive critique see Andrian Schenker, "Unreinheit, Sünde und Sündopfer: Kritische Untersuchung zweier verbreiterer Thesen: befleckende Sünde (moral impurity) und Sündopfer chatta’t als Reinigunsopfer für das Heiligtum,” Biblische Zeitschrift 59/1 (2015): 1-16.

74 Milgrom, "Systematic Differences,” 324. 
Point number 2 above, summarizing Klawans's view, does not seem applicable to the Chronicler's "imprecise" understanding of things either. If moral impurity such as idolatry cannot contaminate through contact, then how did the temple and Judah become polluted in the stories of Hezekiah and Josiah? By the presence of foreign cultic objects? But is that not contact? Similar to touching a dead body or a person with צָרֵַַת etc.? I argue this is indeed a case of contact and that for the Chronicler the very fact that these foreign objects were carried into the temple and Jerusalem meant contamination which needed cleansing. Thus, impurity terms are used to describe a sin such as idolatry. What was the solution?

As I tried to argue concerning 2 Chronicles 29, the author has some idea of

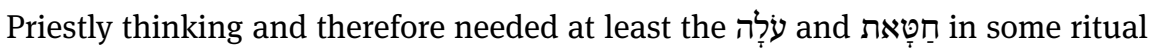
reminiscent of the Yom Kippur. But this followed after some "cleansing” by simply removing what did not belong there. What cleanses here is not sacrifice, but merely stopping what you did wrong. Still, the Chronicler felt the need for sacrifice, even if afterwards. It could very well be that for the Chronicler טהר simply meant cleaning and not our ritualised cleansing. Still, I argue that the very fact that מַטְָאת as the purification offering and verbs such as טהר occur in such proximity means that the authors had some understanding of Priestly views of pollution. It is also noteworthy that after the mention of חַטָאת towards the end of 2 Chronicles, impurity language is used for the first time. ${ }^{75}$ In short, it seems that there was some kind of priestly thinking going on, but much more haphazardly than in Leviticus. Yet even if the Chronicler gives the impression that the problem of idolatry can be solved, it is clear that it was not a permanent solution as impurity language is used again toward the end:

\begin{tabular}{|c|c|}
\hline 2 Chronicles 36:14 (BHS SESB 2.0) & 2 Chronicles 36:14 (NRSV) \\
\hline 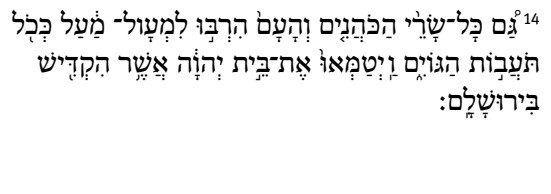 & $\begin{array}{l}{ }^{14} \text { All the leading priests and the people also } \\
\text { were exceedingly unfaithful, following all the } \\
\text { abominations of the nations; and they polluted } \\
\text { the house of the LoRD that he had consecrated } \\
\text { in Jerusalem. }\end{array}$ \\
\hline
\end{tabular}

The next verse starts to tell the story of the fall of Jerusalem. Thus, even if the texts where we find the verb טהר seem to indicate that moral pollution could be cleansed, the outcome is still the same as Klawans and the Holiness Code would

75 As Ben Zvi, "Purity Matters,” 41, points out, this kind of language is absent from stories about "cult foundational accounts" in 1 Chronicles 16 and 2 Chronicles 5-7. The focus in these stories was more on "joy, praise and thanksgiving than purity matters." 
have it, namely exile. The crucial question still is: how Priestly is the portrayal of sacrifice in Chronicles?

\section{Conclusion}

The short answer would be that the Chronicler's presentation of the sacrificial cult is fairly Priestly, but in a very imprecise way.

Concerning the priesthood, the Chronicler refers to Aaron and his sons, which agrees with Leviticus, and they are responsible for reconciliation. But in 2 Chronicles 30:18, a prayer by Hezekiah also leads to atonement, which is something not found in the book of Leviticus. The prayers of the kings thus compete with the role of the priests. The following point from Ben Zvi puts it clearly: ${ }^{76}$

When matters of ritual purity and impurity finally come to the fore in a very limited number of accounts, the text seems to deemphasise them or subvert some aspect of the ideological logic that underpins them.

Whereas purity concerns are deemphasised, the role of the Levites is emphasised and they play a much bigger role, even encroaching on the terrain of the priests, an issue which has already been extensively discussed by Chronicles scholars.

Of the five sacrifices found in Leviticus, all the voluntary ones are present.

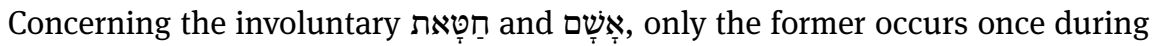
Hezekiah's cleansing of the temple. It is also in this chapter that we found the verb טהר in the Piel referring to the cleansing of the temple, something which happened before the sacrifices were performed. What this cleansing entailed is not clear, but if we take the story of Josiah into account, then it probably had to do with removing images of other gods, which thus implies that the cause of the problem was idolatry. I have tried to show that these examples undermine attempts by scholars such as Klawans to distinguish between ritual and moral impurity.

I have also argued that behind 2 Chronicles 29, there must be some kind of thinking about clean and unclean akin to Priestly thinking on these matters. The

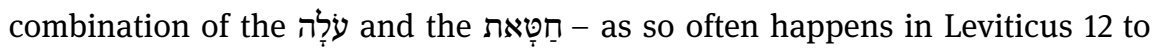
15 , but also in 16 - bears witness to this fact. This thinking does overlap somewhat with Priestly thinking. But the major difference is that that cleansing language occurs before any rituals have taken place and that cleansing language is

76 Ben Zvi, "Purity Matters,” 43. 
not associated with sacrifices like in Leviticus. For the priests who wrote Leviticus, this "impreciseness" of Chronicles would simply not have been adequate. For instance, in Leviticus 14, when the priest sees that the צִּרעת is gone from the person, he cannot merely pronounce him clean as soon as the source of his uncleanness is gone. A ritual, including some sacrifice, is required. It is only after the ritual with the two birds, cedarwood, crimson yard and hyssop had been concluded that the priest would declare the person clean and then some more sacrifices and rituals would follow. Thus, although there might be some overlap, there are also significant differences.

In light of the debate on ritual or bodily impurity and moral impurity, Chronicles paints a complex picture. It is not clear that the Chronicler was familiar with this distinction, and if he were, he blurred the distinction. The most evident reference to ritual impurity seems to be chapter 30 and the celebration of the Pesach. The clearest reference to moral impurity is found in the two stories of Hezekiah and Josiah cleansing the temple, as well as the city and Judah (in the case of Josiah). Yet this very act of cleansing of moral impurity contradicts the usual definitions of moral impurity. In the end, though, the outcome is the same as for all moral impurity, namely the land and temple could not be cleansed, and this resulted in the people being removed from the land into exile. 
